\title{
PRISPEVEK K PROUČEVANJU REGIONALNO- GEOGRAFSKIH RAZSEŽNOSTI OBLIKOVANJA MESTNIH REGIJ V SLOVENIJI V POGOJIH GLOBALIZACIJE IN TRAJNOSTNO SONARAVNEGA RAZVOJA
}

\begin{abstract}
Marjan Ravbar*, Dušan Plut ${ }^{* *}$
Izvleček

Avtorja v prispevku ugotavljata, da se tudi v Sloveniji že sluti spontano oblikovanje razvojnih osi, povezanih v enotna gospodarsko-geografska območja. Določajo jih omrežja tistih mest, ki so med seboj povezana s trgom delovne sile, z ustrezno prometno in gospodarsko infrastrukturo ter $z$ ostalo komunikacijsko opremo. Oblikovanje razvojnih zaposlitvenih osi podpira zlasti dezurbanizacija, ki že prerašča dejansko urbanizacijo.
\end{abstract}

Ključne besede: Geografski vidiki globalizacije, urbanizacija, vloga mest, trajnostno sonaravni urbani razvoj
CONTRIBUTION TO RESEARCH OF REGIONAL-GEOGRAPHIC DIMENSIONS
OF FORMATION OF CITY REGIONS IN SLOVENIA IN CONDITIONS OF GLOBALIZATION AND SUSTAINABLE DEVELOPMENT

\begin{abstract}
Authors state in the article that spontaneous formation of development axis could be anticipated also in Slovenia, which are linked into uniform economic-geographic areas. The said axes are defined by the network of cities which are linked among themselves with market of manpower, with suitable traffic and economic infrastructure and with other communication equipment. Formation of development employment axis is supported particularly by dezurbanization which is already overgrowing the real urbanization.
\end{abstract}

Key words: Geographic aspects of globalization, urbanization, role of cities, sustainable urban development

\footnotetext{
* Dr. Inštitut za geografijo, Trg francoske revolucije 7, SI 1000 Ljubljana, Slovenija.

** Dr. izred. prof., Oddelek za geografijo, Filozofska fakulteta Univerze v Ljubljani, Aškerčeva 2, SI 1000 Ljubljana, Slovenija.
} 


\section{UVOD}

Slovenija je v povojnem razvoju zaradi deagrarizacije, industrializacije, urbanizacije, intelektualizacije, itd. - skratka zaradi vse obsežne modernizacije družbe, bistveno spremenila zaposlitveno, gospodarsko in prebivalstveno strukturo. Sodobni regionalni, naselbinski, demografski in regionalni razvoj se $\mathrm{v}$ temeljih ne razlikuje od strukturnih sprememb v Srednji Evropi. Markantna je gospodarska krepitev mest in širitev njihovih sub- in peri-urbaniziranih vplivnih območij, povezanih $s$ koncentracijo delovnih mest $\mathrm{v}$ služnostnih dejavnostih (Messerli/Perlik, 1997). Podobne procese opazujemo tudi $\mathrm{v}$ Sloveniji, čeprav so aglomerativne in metropolitanizacijske sposobnosti mest občutno manjše in slovenska mesta v evropski hierarhiji mest ne igrajo pomembnejše vloge. Pa vendarle ljubljanska, mariborska in tudi ostale mestne regije (celjska, somestje obalnih mest, ...) stopajo v ospredje kot generatorji prostorskega in regionalnega razvoja. $\mathrm{V}$ zadnjih treh desetletjih se je število prebivalstva povečalo za petino (124 \%), v mestih in urbaniziranih obmestjih pa za polovico (146\%). V tem obdobju so imela najbolj intenzivno rast poleg mest še urbanizirana obmestja, kjer je bila povprečna letna stopnja rasti med 1,64 \% in 1,73 $\%$. Na prelomu tisočletja se že sluti spontano oblikovanje razvojnih osi, povezanih v enotna gospodarsko-geografska območja. Določajo jih omrežja tistih mest, ki so med seboj povezana $\mathrm{s}$ trgom delovne sile, $\mathrm{z}$ ustrezno prometno - "mrežno" ter "koridorsko" gospodarsko infrastrukturo in $\mathrm{z}$ ostalo komunikacijsko opremo. Oblikovanje razvojnih zaposlitvenih osi podpira zlasti dezurbanizacija, ki že prerašča dejansko urbanizacijo (Ravbar, 1997).

Druga posebnost je še $\mathrm{v}$ zapoznelem, zato pa nadpovprečno hitrem poteku strukturnih sprememb v regionalnem razvoju. Spremembe v gospodarski zgradbi so bile posledica delovanja številnih, kompleksnih in nasprotujočih si procesov (urbanizacija, deagrarizacija, depopulacija, zemljiško-posestne razmere, intenzifikacija in diverzifikacija podeželja, pomanjkanje inovativnosti in razvojnih spodbud na podeželju, ...). Zaposlenost prebivalstva je do sredine druge polovice osemdesetih let naglo naraščala. Po letu 1987 sledimo gospodarski in družbeni krizi, pozneje povezani še s spremembo družbenega sistema, ki se odraža v zmanjševanju števila delovnih mest in povečani stopnji brezposelnosti. V zadnjem desetletju se je število delovnih mest zmanjšalo za četrtino (73\%), število brezposelnih pa povečalo za osemkrat. Vse to je povzročilo opazne strukturne spremembe $\mathrm{v}$ zaposlenosti aktivnega prebivalstva. Od prevlade primarnega sektorja, je v strukturi aktivnega prebivalstva prišlo najprej do prevlade sekundarnega sektorja, v zadnjih letih pa terciarnega in kvartarnega oz. služnostnih dejavnosti.

Kmetijstvo že nekaj časa nima odločujoče vloge v gospodarskem razvoju. Obmestni razvoj podeželja je vse bolj odvisen od bližnjega urbanega - zaposlitvenega jedra. Celoten migracijski ciklus (podeželje - mesto - urbanizirano podeželje), za katerega so današnje visoko razvite evropske države potrebovale obdobje treh generacij, se je v Sloveniji zgodil v obdobju ene generacije. 


\section{GLOBALIZACIJA IN GEOGRAFSKI VIDIKI RAZVOJA SLOVENIJE IN NJENIH MEST}

"Globalizacija" je v sodobnosti eden izmed ključnih pojmov v politiki, v gospodarstvu, v znanosti. Izhaja iz ameriške "menažerske šole". Razlikujejo tri različne stopnje: "internacionalizacijo", "globalizacijo" in "transnacionalizacijo". Vsaka izmed njih pomeni nadaljnjo intenizifikacijo usmerjeno nasproti "komunikacijski družbi" s pomočjo "informacijskih tokov". Globalizacija je torej vseobsežen proces, ki ga oblikuje dinamičen pretok dobrin, kapitala in tehnologije kar države $\mathrm{z}$ različno stopnjo razvitosti in ekonomskimi sistemi vse bolj sili $\mathrm{v}$ medsebojno odvisnost. Pojem globalizacija je vse bolj aktualen tudi $\mathrm{v}$ tistih znanostih, ki se ukvarjajo $\mathrm{s}$ proučevanjem organizacije prostora in $\mathrm{z}$ razmerji $\mathrm{v}$ gospodarski strukturi pokrajine. Globalizacija krepi konkurenčnost med gospodarskimi pokrajinami, še posebej pa med mesti oz. mestnimi regijami, ki predstavljajo "motorje" regionalnemu razvoju. Položaj, razvoj in vloga mest $\mathrm{v}$ njihovi hierarhiji, se v pogojih svetovnega tekmovanja spreminja. Klasični modeli centralnih krajev, temelječi na pomembnosti oskrbnih funkcij mestnih sistemov, ki so jih izžarevali $\mathrm{v}$ svojo okolico, stopajo v ozadje. Kot kriteriji opazovanja globalizacijskih procesov stopajo $\mathrm{v}$ ospredje ekonomsko-funkcijski kazalci. V sodobnosti lahko uspešno konkurirajo le mesta, ki izkazujejo raznovrstnost produkcijskih struktur in organizacijskih oblik svojih regionalnih struktur. Konkurenčnost mesta oz. mestne regije ni več določena zgolj z njegovim geografskim položajem in $\mathrm{z}$ infrastrukturno opremljenostjo, marveč s proizvodnim in regulacijskim sistemom, ki ga sestavljajo kvaliteta industrijske proizvodnje, finančnih in oskrbnih aktivnosti ter simbioza institucionalnih gospodarskih resursov dotične mestne regije (gl. preglednico št. 1).

Preglednica 1: Globalizacijski razvoj in njeni poglavitni kazalci

\begin{tabular}{|c|c|}
\hline Okvirni pogoji za globalizacijski raz & Poglavi \\
\hline $\begin{array}{l}\text { povečevanje svetovne trgovine kot } \\
\text { posledica deregulacije svetovnega trga } \\
\text { ter zmanjševanje stroškov pri } \\
\text { blagovnih in transportnih storitvah } \\
\text { (liberalizacija svetovne trgovine); }\end{array}$ & $\begin{array}{l}\text { primerjalno hitrejša rast svetovne trgovine } \mathrm{v} \\
\text { primerjavi z volumnom rasti proizvodnje; } \\
\text { razvoj inovacij na področju komunikacijske } \\
\text { tehnologije, npr: Internet, razrast podjetij z } \\
\text { mednarodnim kapitalom; }\end{array}$ \\
\hline $\begin{array}{l}\text { nenehen in pospešen razvoj } \\
\text { informacijskih in komunikacijskih } \\
\text { tehnologij in s tem povezano "mrežno" } \\
\text { prepletanje; }\end{array}$ & $\begin{array}{l}\text { novi obsežni in neodvisni kapitalski trgi (off- } \\
\text { shore), izgrajevanje trans nacionalnih podjetij, } \\
\text { bogata ponudba specializiranih "business } \\
\text { servicies" }\end{array}$ \\
\hline $\begin{array}{l}\text { globalna dostopnost do trga kapitala } \\
\text { kot posledica deregulacije kapitalskih } \\
\text { trgov in prepletanja informacij; }\end{array}$ & $\begin{array}{l}\text { pokrajinska mikavnost ("natural amenities"), } \\
\text { - atraktivna kulturna ponudba z uspešnim } \\
\text { izobraževalnim sistemom ("cultural ame- }\end{array}$ \\
\hline $\begin{array}{l}\text { "nove" smeri v } \quad \text { mobilnosti } \\
\text { prebivalstva, proizvodnih } \\
\text { delovnih mest. }\end{array}$ & $\begin{array}{l}\text { nities"), koncentracija visoko kvalificiranih } \\
\text { strokovnjakov, - atraktivni in ceneni bivalni } \\
\text { pogoji ter že izgrajeno infrastrukturno } \\
\text { omrežje. }\end{array}$ \\
\hline
\end{tabular}

Vir: Povzeto po: Fuchs, 1998 
Pomembno vlogo imajo še inovativna razvojna politika, ki jo sestavljajo socialno in kulturno okolje, oblikovanje (med)regionalnih omrežij, tehnološki transfer (izmenjava informacij), odprtost in zaupanje, podjetniško svetovanje, mobilnost delovne sile, regionalna identiteta, opremljenost s kulturnimi institucijami (sponzorstvo), visoki potenciali za rekreacijo in prosti čas, različne socialne aktivnosti, visoka stopnja biotske ohranjenosti okolja, visoko postavljeni standardi kvalitete življenja in kultura upravljanja, torej elementi, ki oblikujejo ustvarjalno okolje.

Izkušnje po svetu so pokazale, da so $\mathrm{v}$ procesu družbene restrukturacije največ pridobila tista območja, ki so $\mathrm{v}$ urbaniziranih središčih $\mathrm{s}$ selektivno koncentracijo razvojnih potencialov uspela razviti novo razvojno tehnologijo. Ta središča hkrati razvijajo nove oblike oskrbnih dejavnosti, ki so prav tako nosilci nadaljnje razvojne ekspanzije. V globalnih procesih restrukturacije se običajno pojavljajo: (a) fleksibilizacija proizvodnje in trga delovne sile, (b) internacionalizacija produkcije in mobilnost kapitala, (c) opuščanje "realne" proizvodnje $\mathrm{z}$ namenom aktiviranja "prostega" kapitala (d) deregulacija podedovanih politično-institucionalnih davčnih mehanizmov (e) dokapitalizacija spektra družbenih področij (f) polarizacija in hierarhizacija zaposlitvenih središč. V mestnih regijah in zgostitvenih območjih prihaja istočasno do decentralizacije in dekoncentracije proizvodnih kapacitet ob istočasni centralizaciji finančnih in drugih "kontrolnih" funkcij. Aglomeracijske tendence se ne odražajo le na področju modernih tehnologij, marveč tudi na področju novih "fleksibilnih" proizvodenj.

Regionalni razvoj Slovenije je vedno bolj odvisen od vpetosti v omrežje evropskih ekonomij ("network economies"). Gospodarski razvoj mest in mestnih regij je namreč neločljivo povezan $\mathrm{z}$ razvojem produkcije, finančnega gospodarstva in služnostnih dejavnosti. Zaradi vpetosti mestnih ekonomij $\mathrm{v}$ mednarodno delitev dela, rasti pomena multi nacionalnih podjetij in krepitvijo novih komunikacijskih sistemov, se širijo funkcionalna prepletanja med vedno večjimi prostorsko zaokroženimi območji, ne oziraje se na politične meje. Prav zato izolirano proučevanje mest ni več upravičeno. Za slovenska mesta je tudi pomembno, da leže ob evropskih razvojnih oseh in relativno blizu njenih vozlišč ${ }^{1}$ ali pa jih je vsaj s tim. "hitrimi priključki" možno povezati z enim od teh vozlišč (gl. preglednico 2).

Pričujoči prispevek se je v nadaljevanju osredotočil na prikaz regionalno-geografskih razsežnosti oblikovanja mestnih regij $\mathrm{v}$ nastajajočih pogojih ustvarjalnega okolja in trajnostno sonaravnega razvoja, kjer poskušamo prikazati "nove" smeri v mobilnosti prebivalstva, spremembe $\mathrm{v}$ razvoju delovnih mest $\mathrm{v}$ izbranih primerih mestnih regij $\mathrm{v}$ Sloveniji.

\footnotetext{
1 npr: mesta ob tim. "modri banani" ali "mediteranskem sunbeltu" in naraščujočem pomenu "inducirajočih" ali "High-Tech" območjih velikih Srednjeevropskih mest kot so Dunaj, Praga, Budimpešta...
} 
Preglednica 2: Sintetični prikaz prednosti in slabosti slovenskih mest v luči njihovega geografskega položaja

\begin{tabular}{|c|c|}
\hline MOČ IN I & SLABOSTI IN RAZVOJNE OVIRE \\
\hline $\begin{array}{l}\text { pomemben geostrateški položaj } \\
\text { pomemben položaj na stiku Alp, Jadrana } \\
\text { in Panonske nižine } \\
\text { dobra prometna dostopnost do } \\
\text { "Evropskih" koridorjev; } \\
\text { ugodna longitudinalna in prečna pro- } \\
\text { metna lega; } \\
\text { pomembno prometno vozlišče (ljubljanska } \\
\text { in postojnska vrata); } \\
\text { pomembna vloga Koprskega pristanišča; } \\
\text { naravno geografske prednosti za razvoj } \\
\text { transportnih sistemov } \\
\text { osrednja lega in metropolitanizacija } \\
\text { Ljubljane; } \\
\text { dosežen količinski in kvalitativni razvojni } \\
\text { prag ter koncentracija znanja v Ljubljani } \\
\text { (in deloma v Mariboru) z raznovrstnostjo } \\
\text { ponudbe; } \\
\text { urbana dekoncentracija in vitalnost } \\
\text { manjših urbanih središč; } \\
\text { kakovosten stanovanjski fond } \\
\text { enodružinskih stanovanjskih hiš; } \\
\text { tradicija samograditeljstva, sosedske } \\
\text { pomoči, lokalnih gradbeno-obrtnih } \\
\text { storitev...; }\end{array}$ & \begin{tabular}{|l} 
- \\
slabo razvita prometna in komunikacijska \\
infrastruktura, (neusklajenost med različnimi \\
oblikami infrastrukture in transporta); \\
slabe prečne prometne povezave, pomanjkanje \\
(med-regionalnih) povezav; \\
socialno-ekonomsko "zapiranje" proti JV; \\
nizka gostota sodobne prometne mreže, ki znižuje \\
gospodarsko učinkovitost infrastrukture; \\
odsotnost specializiranih distribucijskih površin; \\
nizka stopnja urbanizacije - slovenska mesta so \\
premajhna in premalo razpoznavna v konkurenci \\
evropskih mest, nerazvito omrežje regionalnih \\
središč; \\
nezadosten količinski in kvalitativni razvojni prag \\
ter koncentracija znanja v preostalih središčih \\
regionalnega pomena z raznovrstnostjo ponudbe \\
odsotnost trdnejših razvojnih konceptov in \\
urbanističnih planov; \\
pomanjkljiva in predraga mestna in regionalna \\
infrastruktura; \\
pomanjkanje stanovanj v večjih mestih; \\
prenova mestnih središč se v glavnem ne izvaja; \\
razpršena poselitev - črne gradnje in toleranca do \\
njih - tradicionalno neuspešna politika pravnih in \\
represivnih poskusov odpravljanja črnih gradenj
\end{tabular} \\
\hline
\end{tabular}

\section{OBSEG IN RAZSEŽNOSTI URBANIZACIJE V IZBRANIH MESTIH, POVEZANIH Z OPREDELJEVANJEM VLOGE MEST V REGIONALNEM RAZVOJU}

$\mathrm{Z}$ metodološke in teoretske plati obstajajo številni poskusi kvantitativnih in kvalitativnih izpeljav vrednotenja vplivov mest na regionalni razvoj z ekonomske, socialne, naselbinske, infrastrukturne ali ekološke plati. S praktične plati pa je izjemno težko s kvalitativnimi kazalci določiti dominantno stopnjo le določeni izbrani skupini indikatorjev.

Poglavitni namen vrednotenja temelji na poskusu zaznavanja diferenciacije urbanizacijskih modalitet $\mathrm{v}$ funkciji regionalnega razvoja, ki je posledica mozaične pestrosti slovenskih pokrajin in prilagajanja naravnih, ekonomskih in socialnih (življenjskih) pogojev standardom, ki jih nudijo mesta s svojimi urbaniziranimi območji. Pri ugotavljanju obsega mestnih vplivov smo izhajali iz gospodarske strukture in trga delovne sile, kjer smo izhajali iz meril, kot so ekonomska moč, kvaliteta delovnih mest in brezposelnost, naselbinske strukture $\mathrm{z}$ merili kot so socialna, ekonomska in fiziognomska struktura naselij, osebnega standarda 
prebivalcev in infrastrukturne opremljenosti območij (družbena in gospodarska infrastruktura) ter naravnih virov (kmetijske površine) in stanja okolja kot pomembnih gibal regionalnega razvoja. Izbor kriterijev je prilagojen na eni strani statistično merljivim kazalcem, ki so enostavni in razumljivi. Na tej podlagi smo razvili izbor indikatorjev, upoštevajoč dostopno statistično gradivo.

Poseben poudarek smo namenili skupini kazalcev, ki poskušajo celovito zajeti vse najpomembnejše značilnosti sodobnih urbanizacijskih vplivov v pokrajini. Pri vrednotenju mestnih vplivov smo se odločili za uporabo socialno-geografskih, fiziognomskih, strukturnih in funkcijskih kriterijev: Med socialno-geografskimi indikatorji se kot najpomembnejši kriterij običajno navajajo velikost aglomeracije, gibanje in gostota ter selitvena mobilnost prebivalstva. Pri funkcijskih metodah smo kot kriterije uporabili gospodarske in druge vezi med prebivajočimi in zaposlenimi ter prometne povezave ali dnevno migracijo zaposlenih. Pri fiziognomskih kriterijih smo uporabili dinamiko stanovanjske gradnje in $\mathrm{v}$ okviru tega še delež individualnih hiš od skupnega stanovanjskega fonda. Pri določanju poselitvenih kriterijev smo sodili, da seštevek števila prebivalstva in delovnih mest na enoto površine nazorno odslikava prepletanje populacijskih, bivalnih razmer in tudi delovnih pogojev kot odločujočih "lokacijskih" faktorjev za oblikovanje preobrazbe naselbinskih območij. Pri razmestitvi delovnih mest smo izhajali iz gostote delovnih mest $\mathrm{v}$ številu prebivalcev, razmerja med delovno aktivnim prebivalstvom in delovnimi mesti ter spreminjanjem le-teh. Pri izobrazbeni ravni prebivalstva smo kot kriterij uporabili delež prebivalcev z najmanj srednjo ter višjo in visokošolsko izobrazbo. Ob izboru smo se naslonili tiste kazalce, ki izražajo geografske sestavine temeljnih funkcij človekovega delovanja, predvsem bivanja in dela. $Z$ njimi smo hkrati želeli pokazati vsaj na tri razsežnosti, ki jih prinaša urbanizacija: na spremembe $v$ fizičnem razvoju naselij, na spremembe $v$ socialni strukturi območij in posredno še na spremembe $v$ "sistemu kulturnih vrednot", ki jih prinaša novi "obmestno naravnani način življenja", vzpodbujen z urbanizacijo.

Urbanizacijski vplivi so izmerjeni na podlagi ekonomsko- in socialno-geografskih ter fiziognomskih, strukturnih in funkcijskih kriterijev (več o tem v: Ravbar, 1997a). Na ta način so nam mestne regije razpadle v naslednje skupine:

1. mesta (po statistični klasifikaciji naselij);

2. suburbanizirana obmestja;

a) ožja suburbanizirana obmestja;

b) močno urbanizirana obmestna naselja.

Izsledki, ki smo jih dobili s prikazano tipologijo so nam med slovenskimi naselji dali naslednjo sliko: Mesta, ki predstavljajo 1,2\% slovenskih naselij (v njih pa prebiva dobra polovica ljudi), je obkrožal najprej venec 281 (5 \%) naselij v najožji suburbanizirani okolici in nato še $658(11 \%)$ močno urbaniziranih obmestnih naselij. Ostala urbanizirana, urbanizirana podeželska in pol urbanizirana - prehodna območja 
naselij pa so štela še nadaljnjih 964 (16 \%) naselij, medtem ko se je preostalih 3942 naselij uvrstilo med podeželska naselja. Analiza je nadalje pokazala, da je urbanizacijska stopnja $v$ Sloveniji $65 \%$, ter da je tretjina republike zelo močno urbanizirana, kjer $\mathrm{v}$ urbaniziranih naseljih prebiva več kot devet desetin njenega prebivalstva. Najvišja stopnja urbaniziranosti je v savski dolini od Jesenic do Ljubljanskega polja, na Kamniško-Bistriški ravnini, ob Obali, na Goriškem, Kočevskem, Zasavju, Celjski in Šaleški dolini in Dravsko-ptujskem polju.

Še podrobnejši postopek vrednotenja smo izvedli v zgoraj naštetih območjih. Torej v obmestjih največjih mest in sicer na ljubljanskem metropolitanskem območju, vključujoč gorenjska mesta, Mariboru z mesti na Dravsko-ptujskem polju, somestju obalnih mest, mestih v Savinjski dolini in Velenjski kotlini ter Novi Gorici, Novem mestu in Murski Soboti. V postopek vrednotenja so bila tako vključena vsa največja in najobsežnejša urbanizirana območja v Sloveniji z metropolitanizacijskimi in/ali aglomerativnimi težnjami.

Pri proučevanju regionalno-geografskih razsežnosti oblikovanja mestnih regij $\mathrm{v}$ globalizacijskih pogojih in trajnostno sonaravnega razvoja smo poskusili s socialno geografskimi metodami prikazati "nove" smeri v mobilnosti prebivalstva, proizvodnih središč in delovnih mest. Za opredeljevanje vloge mest smo poskusili razviti kompleksno metodo merjenja vloge mest $\mathrm{v}$ regionalnem razvoju. Zasnovana je tako, da smo hkrati - sočasno poskusili ovrednotili več pojavov in sicer tiste, ki so povezani:

1. $\mathrm{z}$ doseženo stopnjo urbanizacije in širjenjem mestnih vplivov v bližnja obmestja;

2. $\mathrm{z}$ razmestitvijo delovnih mest $\mathrm{v}$ urbaniziranih območjih;

3. $\mathrm{z}$ izobrazbeno ravnijo prebivalstva in

4. s kakovostjo bivalnega okolja.

Analitično podlago so nam predstavljala močno urbanizirana območja $\mathrm{v}$ mestnih regijah, kjer smo ugotavljali še razmestitev delovnih mest, pri čemer smo upoštevali le naselja $\mathrm{z}$ več delovnimi mesti od aktivnega prebivalstva; pri izobrazbeni strukturi prebivalstva pa tista naselja, kjer je več kot $50 \%$ ljudi z najmanj srednješolsko izobrazbo. Ob izboru smo se torej naslonili na tiste kazalce, ki izražajo geografske sestavine temeljnih funkcij človekovega delovanja, predvsem bivanja in dela, povezanega $\mathrm{z}$ elementi izobrazbene ravni kot pomembnega elementa za določanje ustvarjalnega okolja. Z njimi smo hkrati želeli pokazati vsaj na tri razsežnosti, ki jih prinaša urbanizacija: na spremembe $\mathrm{v}$ fizičnem razvoju naselij, na spremembe $\mathrm{v}$ socialni in zaposlitveni strukturi območij in širjenje mestnih vplivov v "sistemu kulturnih vrednot", ki jih prinaša difuzija "obmestno naravnanega načina življenja", vzpodbujena z urbanizacijo. 
Preglednica 3: Razmestitev števila prebivalcev in delovnih mest $\mathrm{v}$ izbranih mestnih regijah

\begin{tabular}{|c|c|c|c|c|c|c|c|c|}
\hline 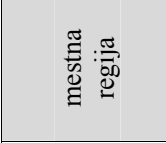 & 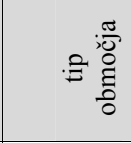 & 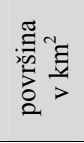 & 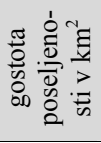 & 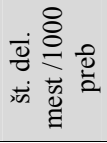 & 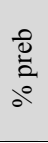 & $\begin{array}{l}\vec{v} \\
\stackrel{8}{\Xi} \\
\dot{\Phi} \\
\dot{0} \\
0^{\circ}\end{array}$ & 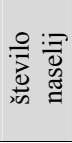 & 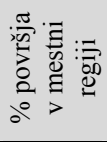 \\
\hline \multirow{4}{*}{ Ljubljana } & mesta & 246,4 & 1484,5 & 603,9 & 75 & 87 & 5 & $38 \%$ \\
\hline & suburb. & 113,0 & 222,3 & 294,0 & 16 & 9 & 112 & $18 \%$ \\
\hline & obmestja & 281,9 & 112,7 & 204,7 & 10 & 4 & 148 & $44 \%$ \\
\hline & skupaj & 641,3 & 481,4 & 516,2 & & & & \\
\hline \multirow{4}{*}{ Maribor } & mesta & 61,5 & 2073,6 & 570,4 & 59 & 82 & 3 & $11 \%$ \\
\hline & suburb. & 370,5 & 255,4 & 225,7 & 16 & 9 & 44 & $66 \%$ \\
\hline & obmestja & 131,4 & 146,7 & 146,7 & 25 & 9 & 115 & $23 \%$ \\
\hline & skupaj & 563,4 & 382,3 & 409,7 & & & & \\
\hline \multirow{4}{*}{ Kranj } & mesta & 109,7 & 641,1 & 540,7 & 59 & 79 & 7 & $18 \%$ \\
\hline & suburb. & 352,2 & 168,8 & 185,9 & 17 & 8 & 51 & $56 \%$ \\
\hline & obmestja & 164,3 & 106,2 & 217,7 & 23 & 13 & 118 & $26 \%$ \\
\hline & skupaj & 626,2 & 240,6 & 403,7 & & & & \\
\hline \multirow{4}{*}{ Celje } & mesta & 48,2 & 1663,9 & 632,2 & 66 & 82 & 5 & $24 \%$ \\
\hline & suburb. & 90,8 & 277,1 & 321,5 & 14 & 9 & 30 & $46 \%$ \\
\hline & obmestja & 58,0 & 161,8 & 233,3 & 20 & 9 & 56 & $29 \%$ \\
\hline & skupaj & 197,0 & 466,4 & 508,1 & & & & \\
\hline \multirow{4}{*}{$\begin{array}{l}\text { Obalna mesta } \\
\text { (Koper, } \\
\text { Izola, } \\
\text { Piran) }\end{array}$} & mesta & 12,4 & 3433,2 & 554,6 & 61 & 79 & 4 & $10 \%$ \\
\hline & suburb. & 43,6 & 309,5 & 272,2 & 28 & 17 & 16 & $37 \%$ \\
\hline & obmestja & 62,3 & 173,1 & 148,3 & 11 & 4 & 21 & $53 \%$ \\
\hline & skupaj & 118,3 & $\mathbf{5 8 7 , 1}$ & 432,0 & & & & \\
\hline \multirow{4}{*}{ Nova Gorica } & mesta & 3,5 & 4077,7 & 668,4 & 36 & 46 & 1 & $3 \%$ \\
\hline & suburb. & 72,9 & 291,1 & 625,5 & 34 & 41 & 10 & $59 \%$ \\
\hline & obmestja & 46,4 & 165,4 & 219,8 & 30 & 13 & 29 & $38 \%$ \\
\hline & skupaj & 122,8 & 325,6 & 518,7 & & & & \\
\hline \multirow{4}{*}{$\begin{array}{l}\text { Novo } \\
\text { mesto }\end{array}$} & mesta & 30,2 & 744,0 & 809,6 & 67 & 86 & 1 & $24 \%$ \\
\hline & suburb. & 71,7 & 119,8 & 238,1 & 8 & 3 & 16 & $57 \%$ \\
\hline & obmestja & 23,6 & 117,3 & 275,4 & 25 & 11 & 37 & $19 \%$ \\
\hline & skupaj & 125,5 & 268,5 & 628,3 & & & & \\
\hline \multirow{4}{*}{$\begin{array}{l}\text { Murska } \\
\text { Sobota }\end{array}$} & mesta & 14,5 & 952,2 & 980,1 & 68 & 87 & 1 & $23 \%$ \\
\hline & suburb. & 41,7 & 335,8 & 164,4 & 9 & 2 & 2 & $67 \%$ \\
\hline & obmestja & 5,7 & 110,3 & 389,5 & 23 & 11 & 7 & $9 \%$ \\
\hline & skupaj & 61,9 & 328,2 & 769,8 & & & & \\
\hline
\end{tabular}

Vir: Statistični urad RS, lastni izračuni.

106 
Analiza je pokazala, da v osmih največjih aglomeracijah - na okoli $12 \%$ slovenskega teritorija, kjer je hkrati več kot tri četrtine vseh delovnih mest, prebiva skoraj dve tretjini slovenskega prebivalstva. Tudi gostota poseljenosti je tri do šestkrat višja od državnega povprečja. Razmestitev delovnih mest je močno odvisna od stopnje njihove ekonomske in splošne razvitosti. Za manj razvita okolja velja, da koncentrirajo razvoj delovnih mest pretežno $\mathrm{v}$ enem (industrijskem) centru. Razvitejše mestne regije pa imajo praviloma (spontano) razvitih večino naselij z raznovrstno strukturo delovnih mest, ki si sledijo v nizih - "preprogah". Tako se že sluti spontano oblikovanje razvojnih osi, povezanih tudi z razmestitvijo delovnih mest pretežno $\mathrm{v}$ služnostnih dejavnostih. Določajo jih omrežja tistih mest, ki so med seboj povezana v enotno gospodarsko-geografsko območje $\mathrm{s}$ trgom delovne sile, $\mathrm{z}$ ustrezno "mrežno" prometno ter "koridorsko" gospodarsko infrastrukturo in ostalo komunikacijsko opremo. Oblikovanje razvojnih zaposlitvenih osi pospešuje zlasti dezurbanizacija, ki že prerašča dejansko urbanizacijo (Ravbar, 1997).Vrednotenje je še pokazalo, da tu še posebej izstopajo okolja $\mathrm{z}$ izrazito prevlado delovnih mest nad številom aktivnega prebivalstva, ki ga obkroža venec naselij - občin z izrazitejšim deležem dnevne delovne migracije $\mathrm{v}$ številu aktivnega prebivalstva. Izobrazbena struktura je $\mathrm{v}$ obmestjih sicer nižja, ampak z izjemo Novega mesta in Murske Sobote bistveno ne odstopa od tiste v mestih. Delovna mesta pa še vedno izrazito prevladujejo v mestih.

\section{NEKATERI OKOLJSKI KAZALCI SONARAVNEGA RAZVOJA ZA VEČJA SLOVENSKA MESTA (SREDA 90. LET)}

Razen procesov globalizacije se zaradi približevanja okoljskim in razvojnim standardom Evropske zveze slovenska mesta soočajo z zahtevami (trajnostno) sonaravnega razvoja. Po svetovni konferenci ZN o okolju in razvoju leta $1992 \mathrm{z}$ Agendo 21 (1992) so načela sonaravnega razvoja postala sestavina planetarno razvojnih načrtov. Ker pa zahteve Agende 21 in zlasti koncept okoljskega prostora o planetarni enakosti (pravici) prebivalcev glede "dovoljene" količine porabe naravnih virov in količine obremenjevanja okolja prinašajo tudi planetarno okoljsko odgovornost, so kazalci kakovosti mestnega okolja hkrati okoljski kazalci (ne)udejanjanja sonaravnih razsežnosti globalizacije v slovenskih mestih.

Za sredo 90. let smo za večja slovenska mesta (in Trbovlje kot imisijsko po večini kazalcev najbolj pokrajinsko degradirano slovensko mesto) na osnovi razpoložljivih podatkov ocenili doseženo stopnjo trajnostno (ne)sonaravnega razvoja.

Na osnovi ovrednotenja podatkov HMZ RS o kakovosti zraka ter priporočljivih smernicah Svetovne zdravstvene organizacije ocenjujemo, da se je Trbovlje sredi 90. let še vedno uvrščalo v 4. kakovostni razred, Ljubljana v 3. - (4)., Maribor in Celje v 3. kakovostni razred. Ostala obravnavana mesta so se uvrščala v 2. kako-vostni razred. V primerjavi z zakonsko razvrstitvijo $\mathrm{v}$ območja onesnaženosti zraka leta 
1988 se je kakovost zraka bistveno izboljšala zlasti v Mariboru, kar je posledica sistematičnih sanacijskih ukrepov.

Preglednica 4:Večja urbana območja Slovenije - kazalci kakovosti mestnega okolja (sreda 90. let)

\begin{tabular}{|l|c|c|c|}
\hline $\begin{array}{l}\text { URBANO } \\
\text { OBMOČJE }\end{array}$ & $\begin{array}{c}\text { Onesnaženost zraka- } \\
\text { sreda 90. let } \\
\left.\text { (ocena }^{1}\right)(1.1988)\end{array}$ & $\begin{array}{c}\text { Onesnaženost } \\
\text { vod-sreda } \\
90 . \text { let } \\
\text { (sreda 80. let) }\end{array}$ & $\begin{array}{c}\text { Degradirana urbana } \\
\text { območja - sreda 90. let } \\
\text { (\% od skupne } \\
\text { površine mesta) }\end{array}$ \\
\hline Ljubljana & $3-(4)(4)$ & $4(4)$ & $3(10,6)$ \\
\hline Maribor & $3-(2)(4)$ & $2-3(3)$ & $3(14,2)$ \\
\hline Celje & $3(4)$ & $4(4)$ & $3(18,9)$ \\
\hline Murska Sobota & $2(3)$ & $3-4(4)$ & $2(4,0)$ \\
\hline Novo mesto & $2-(3)(3)$ & $3(3)$ & $1(2,5)$ \\
\hline Kranj & $2-(3)(3)$ & $3(3)$ & $2(6,4)$ \\
\hline Nova Gorica & $2(3)$ & $4(4)$ & $3(11,0)$ \\
\hline Koper & $2(3)$ & $2(2)$ & $1(2,2)$ \\
\hline Trbovlje & $4(4)$ & $4(4)$ & $4\left(30,8^{2}\right)$ \\
\hline
\end{tabular}

Vir: poročila MOP - a; Koželj, 1998; Špes, 1998

Onesnaženost mestnih vodnih virov (vodotokov, talne vode ali obalnega morja) je bila tudi sredi 90. let zelo velika, največja (4. razred) v Ljubljani (Ljubljanica), Celju (Voglajna), Novi Gorici (Koren) in Trbovljah (Trboveljščica). V primerjavi s kakovostjo mestnih voda sredi 80 . let je bilo stanje sredi 90 . let v večini primerov nespremenjeno oziroma je prišlo le do rahlega izboljšanja (Maribor, Murska Sobota).

Največji delež urbanih degradiranih območij je v Trbovljah (območje Trbovlje Hrastnik) in sicer skoraj tretjina (31 \%) vseh mestnih površin, zlasti zaradi premogovno degradiranih površin ter rudarskih stanovanjskih kolonij. Večji deleži degradiranih urbanih površin so tudi v starih industrijskih središčih (Celje, Maribor) (Koželj, 1998). Zelo skromen pa je njihov delež v mestih, ki nimajo daljše industrijske tradicije (Novo mesto, Koper, Murska Sobota), z izjemo Nove Gorice.

Z izjemo submediteransko toplega Kopra so bili sredi 90 . let v vseh večjih mestih sistemi plinskega omrežja, le Trbovlje niso priključene na osrednji in lokalni plinovodni sistem, temveč le na lokalni. V vseh mestih je daljinsko ogrevanje, ki je najbolj razvejano $\mathrm{v}$ Ljubljani. Plinifikacija in sistem daljinskega ogrevanja sta pomembno zmanjšala zračne emisije in $\mathrm{s}$ tem kakovost mestnega bivalnega okolja. Zelo zaskrbljujoče pa je stanje glede količin in načinov čiščenja mestnih odpadnih vod. V Ljubljani, Mariboru, Celju, Novi Gorici in Trbovljah sredi leta 1999 ni bilo

1 ocena na osnovi podatkov HMZ RS za leta 1994, 1995 in 1996 ter meril WHO (SO $\mathrm{SO}_{2}$ dim, NOx, indeks kislih plinov)

2 Trbovlje in Hrastnik 
osrednje komunalne čistilne naprave za sekundarno (biološko) čiščenje odpadnih vod, $\mathrm{v}$ nobenem od obravnavanih mest pa ni terciarnega čiščenja odpadnih vod, torej odstranjevanja dušika in fosfatov.

Uveljavljanje načel trajnostno sonaravnega urbanega razvoja $\mathrm{v}$ večjih slovenskih lahko preverjamo tudi s pomočjo primerjave vzorcev pokrajinske rabe in snovno energijskih tokov $\mathrm{z}$ drugimi evropskimi mesti. Glede na število prebivalcev je smiselna le primerjava trajnostno sonaravnih značilnosti Ljubljane $\mathrm{z}$ nekaterimi izbranimi evropskimi mesti. Primerjava rabe prostora Ljubljane $\mathrm{z}$ drugimi evropskimi mesti otežkočajo različni kriteriji za določitev površine mesta, kar zlasti velja za Ljubljano (Preglednica 5).

Preglednica 5: Sonaravni urbani kazalci - vzorci rabe prostora evropskih mest (1. 1993)

\begin{tabular}{|c|c|c|c|c|c|c|c|}
\hline Mesto & 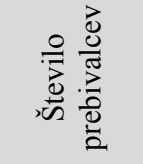 & 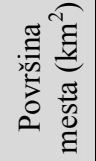 & 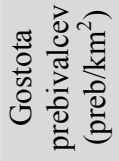 & 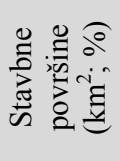 & 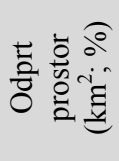 & 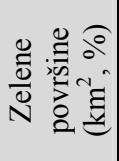 & 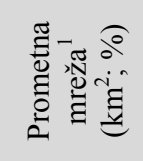 \\
\hline Amsterdam & 718119 & 202 & 3562 & $75 ; 37$ & $62 ; 31$ & $53 ; 26$ & $11 ; 6$ \\
\hline Barcelona & 1508805 & 101 & 14939 & $76 ; 75$ & $25 ; 25$ & $22 ; 22$ & $11 ; 11$ \\
\hline Bruselj & 951580 & 162 & 5974 & $70 ; 43$ & $92 ; 57$ & $86 ; 53$ & $34 ; 21$ \\
\hline Nürnberg & 500000 & 186 & 2688 & $95 ; 51$ & $91 ; 49$ & $83 ; 45$ & $23 ; 12$ \\
\hline Oslo & 488659 & 454 & 1076 & $112 ; 25$ & $342 ; 75$ & $307 ; 68$ & $21 ; 5$ \\
\hline Riga & 826598 & 307 & 2690 & $122 ; 40$ & $186 ; 60$ & $110 ; 36$ & $18 ; 6$ \\
\hline Torino & 923000 & 130 & 7100 & $70 ; 54$ & $60 ; 46$ & $13 ; 10$ & $18 ; 14$ \\
\hline Dunaj & 1636400 & 415 & 3943 & $190 ; 46$ & $225 ; 54$ & $20 ; 5$ & $56 ; 13$ \\
\hline Varšava & 1632424 & 495 & 3298 & $169 ; 32$ & $250 ; 51$ & $130 ; 26$ & $85 ; 17$ \\
\hline Zuerich & 360826 & 92 & 3922 & $44 ; 47$ & $49 ; 53$ & $43 ; 47$ & $13 ; 14$ \\
\hline Ljubljana & 276397 & $\begin{array}{c}272 \\
\left(163^{2}\right. \\
) \\
\end{array}$ & $\begin{array}{c}1016 \\
(1717)\end{array}$ & $\begin{array}{c}38 ; 14 \\
(23 \%- \\
\text { ocena })\end{array}$ & $\begin{array}{l}234 ; 86 \\
(77 \%- \\
\text { ocena) }\end{array}$ & --- & $\begin{array}{c}14 ; 5 \\
\left(8,4 \mathrm{~km}^{2}\right)^{3}\end{array}$ \\
\hline
\end{tabular}

Vir: European Environment Agency, 1998

Kljub temu velja splošna ugotovitev, da je v primerjavi z drugimi evropskimi mesti gostota prebivalstva v Ljubljani relativno nizka, kar kaže tudi relativno nizek delež stavbnih površin (okoli četrtina urbanih površin, v kolikor izhajamo iz manjše ocene površine Ljubljane) $\mathrm{v}$ primerjavi $\mathrm{z}$ odprtim prostorom. Za Ljubljano je značilno, da obsežne zelene površine Golovca, Tivolija, Rožnika segajo v neposredno bližino mestnega jedra. Hkrati pa nizka mestna gostota $\mathrm{v}$ ljubljanskih predmestjih in

1 ceste, parkirišča in železnice 2 Po podatkih MOP - a, 1998 3 ceste, parkirišča 
celotnem obmestnem prostoru pomeni infrastrukturno težavo (zmanjšanje učinkovitosti javnega prometa, težave pri gradnji kanalizacijskega omrežja itd.) in pritisk na kmetijske površine.

V primerjavi z drugimi izbranimi evropskimi mesti so za Ljubljano značilni zmerni snovno - energijski pritiski, preračunani na prebivalca. Značilna je razmeroma velika poraba vode na prebivalca (okoli 150 litrov), ki se praktično ne čisti. Manjša je skupna letna poraba električne energije na prebivalca $(1200 \mathrm{kWh})$, ki posredno kaže na vse manjšo vlogo industrije. Vendar je potrebno upoštevati, da se v Ljubljani električna energija proizvaja $\mathrm{v}$ termoelektrarni - toplarni na premog. Kljub delni uporabi emisijsko primernejšega indonezijskega premoga so energetske emisije TE TO Moste temeljni točkasti vir onesnaževanja mestnega okolja Ljubljane. Letna količina gospodinjskih odpadkov na prebivalca Ljubljane $(370 \mathrm{~kg}$, skupna količina komunalnih odpadkov pa okoli $600 \mathrm{~kg}$ ) je v primerjavi z evropskimi mesti velika, okoli $90 \%$ vseh komunalnih odpadkov pa se odlaga na komunalno odlagališče, ki ne ustreza sodobnim okoljskim predpisom EZ.

Učinkovitost mestne rabe surovin, energije in prostora ter kakovost urbanega okolja je glede na načela 5. akcijskega okoljskega programa EZ (Towards Sustainability, 1995) eden od kazalcev "evropskosti" slovenskih mest. Trajnostno sonaravni kazalci kakovosti mestnega okolja in okoljskih ukrepov potrjujejo, da zlasti večja slovenska mesta in nekatera industrijska ali rudarska mesta ne ustrezajo kriterijem, ki označujejo t.im. sonaravna mesta (suistainable cities). V celoti je več kot tri četrtine vseh mestnih prebivalcev sredi 90. let živelo v mestih z veliko ali zelo veliko onesnaženostjo zraka in vodnih virov (Plut, 1995). Podčrtati velja, da so zlasti podatki o snovno energijskih pritiskih na mestno okolje, posledicah neprimernega ravnanja $\mathrm{z}$ odpadki ter obremenjenosti mestnih prsti še vedno nesistematični. Nujna je izdelava celovitega katastra onesnaževalcev, raziskave snovno - energijskih obremenitev in celovitih, tudi gospodarsko in sonaravno pretehtanih okoljskih sanacijskih mestnih načrtov. V kolikor želijo slovenska mesta tudi po kakovosti okolja konkurirati drugim evropskim mestom, potem morajo biti okoljski sanacijski ukrepi sestavni del razvojne sonaravne strategije.

\section{ZAKLJUČEK}

V strukturi delovnih mest je opazen prehod od sekundarnega $\mathrm{k}$ terciarnemu sektorju in informatiki. Nove tehnologije se odmikajo od »količinske (fordistične)« proizvodnje in stremijo $\mathrm{k}$ fleksibilni (postfordistični), ki temelji na kakovosti, konkurenčnosti in povečani količini znanja. $\mathrm{V}$ teh pogojih sta regionalni in prostorski razvoj v stalni preobrazbi. Zaradi razvoja tehnologij in konkurenčnosti je zmanjšana varnost trajnega delovnega mesta. Še v bližji preteklosti so posamezna območja med sabo izenačevali npr. z ustanavljanjem industrijskih centrov, ki so tedaj pomenili 
diferenciacijo v razvojni moči pokrajine (območja ali mesta). To je bil razvojni vzorec gospodarskega in prostorskega razvoja $\mathrm{v}$ 70-letih. Zaradi pretežno industrijskega razvoja smo tudi razlikovali prosperirajoča in stagnirajoča območja in znotraj njih razvijajoče se predvsem mestne regije. Med njimi in okolico je prihajalo do ekonomsko-socialne polarizacije, ki je privedla tudi do drobne segregacije med posameznimi območji v Sloveniji. Še nedavno tega so imeli takšni industrijski centri, z njimi pa tudi celotne regije pomembno gospodarsko moč, $\mathrm{v}$ njih je bila opazna socialna in prostorska dinamika. Za celotno gravitacijsko zaledje je bila značilna stabilna zaposlenost prebivalstva. Tam, kjer so industrijska središča, ki so temeljila na "fordističnem" principu proizvodnje iz različnih vzrokov zašla v krizo, opažamo poleg upadanja industrijske proizvodnje (deindustrializacija) tudi deinvesticije $\mathrm{v}$ prostorske strukture. Po letu 1990 nastajajo novi, disperzni zametki zaposlitvenih "jeder", stara se le postopno obnavljajo, deloma tudi selijo in ni več klasične delitve na zaposlitveni center in periferijo, ki je bolj ali manj le "dajalec" pretežno nekvalificirane delovne sile. Povečuje se vloga kvalitativnih momentov kot npr. izobrazba, kakovost življenja, ipd kot lokacijskih faktorjev. Zato morajo mestne regije upoštevajoč sodobne lokacijske faktorje, za oblikovanje ekonomsko uspešnih dejavnosti izpolnjevati nekaj pogojev, kajti sodobne dejavnosti pritegnejo:

- območja in naselja s prijazno pokrajinsko mikavnostjo ("natural amenities");

- $\quad$ kraji z atraktivnimi bivalnimi pogoji (pred tistimi s cenenimi bivalnimi pogoji);

- območja $\mathrm{z}$ atraktivno kulturno ponudbo kot tudi z uspešnim šolskim sistemom in možnostmi nadaljnjega izobraževanja ("cultural amenities")

- območja z znanstveno-raziskovalno (tehnološko) tradicijo in sodobno infrastrukturno opremo;

- univerzitetna središča (posebej na naravoslovnem in tehničnih področjih);

- območja s koncentracijo visoko kvalificiranih strokovnjakov $\mathrm{v}$ obstoječih podjetjih z visoko tehnologijo ali tehnoloških parkih (univerzah);

- območja, katerih tamkajšnje zmožnosti so "sposobne tveganja" ("venture capital");

- območja z majhnim deležem industrijskih podjetij, ki onesnažujejo okolje, in območja ki so se odzvala pozivom po okolju prijazni proizvodnji;

- območja z bogato ponudbo specializiranih "business servicies" in so sposobni še naprej "predelovati" proizvode visoke tehnologije;

- območja, ki že dalj časa izkazujejo živahen in stabilen prebivalstveni razvoj;

- območja s prevladujočo srednjo in visokošolsko izobrazbeno strukturo in postopnim neprestanim izboljševanjem te strukture.

- središča z že izgrajenim omrežjem (predvsem) hitrih in drugih sodobnih cest.

$\mathrm{V}$ mestnih regijah in vplivnih območjih prihaja istočasno do prostorske decentralizacije proizvodnih kapacitet ob istočasni prostorski centralizaciji finančnih in drugih "kontrolnih" funkcij. Dekoncentracijske tendence se ne odražajo le na področju modernih tehnologij, marveč tudi na področju novih "fleksibilnih" 
proizvodenj. Zato se $\mathrm{v}$ Sloveniji kot možne strategije regionalnega razvoja tudi na področju zaposlovanja ponujajo naslednje "tipologije": (A) v starih industrijskih središčih najbrž pridejo $\mathrm{v}$ poštev "neo-fordistični" razvojni vzgibi, ki naj na starih "fordističnih" tradicijah iščejo nove proizvode in tehnologije. (B) za vrsto majhnih in srednje velikih središč, čigar proizvodnja še vedno temelji na industrijski produkciji, se ponuja nova paradigma "fleksibilne specializacije".

$\mathrm{Na}$ socialno-ekonomskem področju igra odločujočo vlogo kvalifikacijska in izobrazbena struktura, s katero se povečujejo možnosti vključevanja $v$ inovacijske gospodarske tokove, kajti "od znotraj" določena regionalna identiteta in sociokulturna kreativnost so brez dvoma najmočnejši argumenti. Z ustrezno izobrazbeno strukturo prebivalstva (in kapitala) se oblikuje ustvarjalno okolje, ki praviloma tvori prostorsko zaključeno skupnost, pri čemer so administrativne meje manj pomembne oz. ne predstavljajo nekega posebnega "razpoznavnega" kriterija.

\section{LITERATURA}

- Agenda 21: 1992, Programme of Action for Sustainable Development, United Nations, New York, s. 294.

- Europe's Environment - Statistical Compendium for the Second Assessment, 1998, European Environmental Agency, Luxembourg, s. 156.

- Fürst, D., Ritter, E. H., 1993: Landesentwicklungsplanung und Regionalplanung. Duesseldorf, 36. s.

- Fuchs, G., 1998: Globalisierung - (mehr als) Wirtschaft ohne Grenzen. Praxis Geographie 7-8, str. 7-10.

- Ganser, K., Siebel, W., Sieverts, T., 1993: Die Planungsstrategie der IBA Emscher Park. Eine Annaeherung. Raumplanung H. 61, str. 112-118.

- Klüter, H., 1986: Raum als Element sozialer Komunikation. Giesen.

- Koželj, J., 1998, Degradirana urbana območja, Urad RS za prostorsko planiranje, Ljubljana, s. 252.

- Messerli, P., Perlik, M., 1997: Eine differenzierte Entwicklungspolitik fuer den Alpenraum in Europa. Colloquium Geographicum. Festschrift zum 51. Deutschen Geographentag, Band 24, Bonn, s. 287-302.

- Nationale Regionalförderungsgebiete in Österreich gemaess EU/EWR Wettbewerbsregln, 1996. Atlas zur raumlichen Entwicklung Oesterreichs, Wien.

- Okolje v Sloveniji 1996, 1998, Ministrstvo za okolje in prostor RS, Ljubljana, s. 300

- Plut, D., 1995, Environmental Polution Typology of Slovenian Towns, Geography and Urban Environment, Regiograph, Brno, s. 11 - 22.

- Ravbar, M., 1997: Slovene Cities and Suburbs in Transformation (Slovenska mesta in njihova obmestja $\mathrm{v}$ preobrazbi). Geografski zbornik, št. XXXVII, Ljubljana, (1997), str. 64-109. 
- Ravbar, M., 1997: Zur Siedlungsstruktur Sloweniens. Raumforschung und Raumordnung, Akademie fuer Raumforschung und Landesplanung, 55. Jahrgang, Heft 4/5 (1997), str. 350-358.

- Ravbar, M., 1998: Razporeditev delovnih mest v R Sloveniji v funkciji oblikovanja trga delovne sile. Zbornik referatov: Statistična podpora pogajanjem R Slovenije z Evropsko unijo in strukturni skladi. Statistični dnevi, Radenci 98, str. 237-246.

- Regionale Disparitäten - zwischen Normalität und Handlungbedarf, 1997, Informationen zur Raum-entwicklung, Heft 1/2. Bundesforschungsanstalt für Landeskunde und Raumordnung, Bonn, 143 str.

- S Špes, M., 1998, Onesnaženost in onesnaževanje ozračja in vod, Geografski atlas Slovenije, DZS, Ljubljana, s. 320 - 322

- Towards Sustainability, 1993, Commission of European Communities, Luxembourg, s. 162.

\section{CONTRIBUTION TO RESEARCH OF REGIONAL-GEOGRAPHIC DIMENSIONS OF FORMATION OF CITY REGIONS IN SLOVENIA IN CONDITIONS OF GLOBALIZATION AND SUSTAINABLE DEVELOPMENT}

\section{Summary}

After gaining independence in year 1991 and with the beginning of drawing nearer to European Unit Slovenia and its cities came under strong influence of globalization trends as well as demands of sustainable development. Market openness, competition among European cities, increased importance of quality of living environment lead to changes in hierarchy, power and internal structure of Slovene cities.

We established the presence of elements of the city urbanization and of sustainable development with application of the following groups of indicators:

- with the level of urbanization acquired and with spreading of the influences of the city into the nearest outskirts;

- with arrangement of working places;

- with education level of inhabitants;

- with quality of living environment.

We have selected indicators which reflect geographic components of basic functions of human activity, mostly of living and working from the viewpoint of expected globalization trends. At the same time we wanted to point with the said indicators on at least three extensions, brought out by city globalization and demands of sustainable 
development: changes in physical development of cities, changes in quality of city atmosphere and water sources, changes in social structure of areas and spreading of city influences into the outskirt area.

Evaluation process included all bigger cities, to wit metropolitan area of Ljubljana, including cities of Gorenjska along Sava valley, Maribor with cities on Dravskoptujsko plain, conurbation of coastal cities, cities in Savinja valley and in (ale $\pi$ ka basin, as well as Nova Gorica, Novo mesto and Murska Sobota.

Slovenia has in its postwar development, due to deagrarization, industrialization, urbanization, intellectualization, etc. - in short, due to all extensive modernization of the company, changed essentially employment, economic and population structure. Excessive pollution of air and of water sources occurred in valley basin cities. Also for Slovene cities emphasized economic strength and spreading of their sub- and periurbanized influential areas, connected to the concentration of working places in service activities, is significant. We witness such processes also in Slovenia, although "agglomerate and metropolitanizational" capabilities of cities are significantly smaller and in European hierarchy Slovene cities do not play any important role. However city regions of Ljubljana, Maribor and some others (Celje, conurbation of coastal cities,...) are standing out as generators of spacial and regional development. Number of inhabitants has in the last three years increased for one fifth $(124 \%)$ and in cities and urbanized outskirts for one half $(146 \%)$.

Delayed but over-average fast execution of structural changes in Slovene cities, manifesting also in increased number of unemployed people, represents the second particularity. Employment of inhabitants was increasing rapidly until the midst of the second half of eighties. After year 1987 economic and social crisis took place, which was later on connected also to the change of social system, manifesting in decrease of the number of working places and in increased level of unemployment. Number of working places has in the last ten years decreased for a quarter (73\%), and the number of unemployed people has increased for eight times.

On the break of the millennium spontaneous formation of development axis, linked in uniform economic - geographical areas, is being suspected. The said axis are being defined by the network of cities, linked among themselves with the market of manpower, with corresponding traffic - "network" and - "corridor" economic structure and with other communication equipment. Formation of development employment axis is being supported in particular by dezurbanization which is already overgrowing into real urbanization. A question is arising if spontaneous formation of development axis for Slovene network of cities is a suitable copy of globalization trends, regarding geographic structure, pattern of settlement and limited self-cleaning capabilities of valleys and basins. 